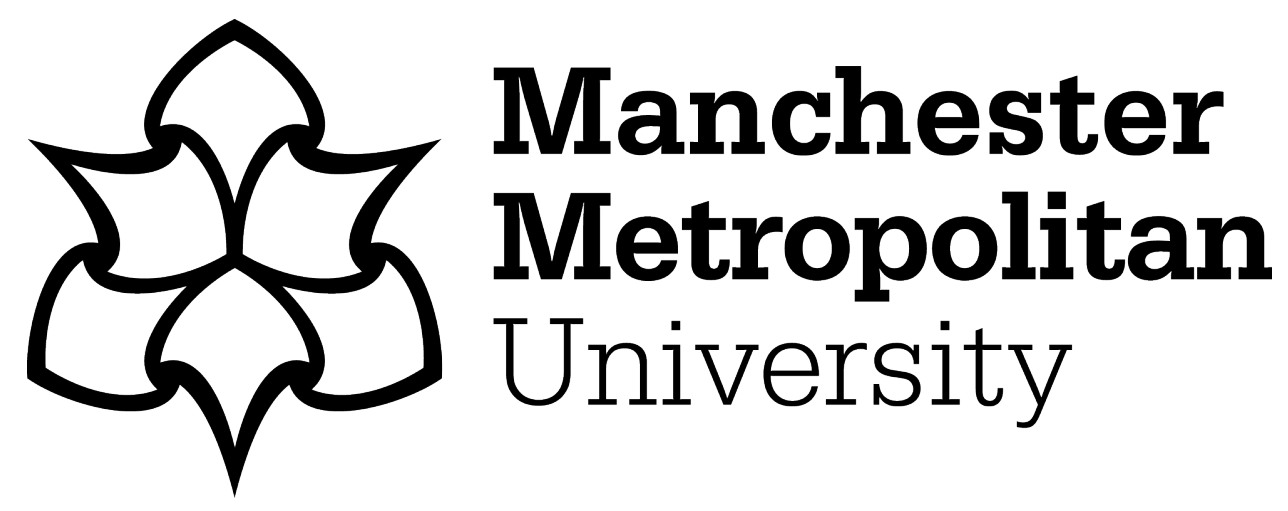

Dillon, Joanne, Evan, Ffion and Wroe, Lauren Elizabeth (2021) COVID-19: changing fields of social work practice with children and young people. Critical and Radical Social Work, 9 (2). pp. 289-296. ISSN 2049-8608

Downloaded from: https://e-space.mmu.ac.uk/627291/ Version: Accepted Version Publisher: Bristol University Press

DOI: https://doi.org/10.1332/204986021x16109919842882

Please cite the published version 


\title{
Covid-19: Changing Fields of Social Work Practice with Children and Young People
}

\begin{abstract}
Drawing on the theoretical work of Wacquant, Bourdieu and Foucault we interrogate how pandemic has weaponized child and family social work practices through reinvigorated mechanisms of discipline and surveillance. We explore how social workers are caught in the struggle between enforcement and relational welfare support. We consider how the illusio of social work obscures power dynamics impacting children, young people and families caught in child welfare systems; disproportionately affecting classed and racialised individuals.
\end{abstract}

\section{Introduction}

This reflexive essay uses Wacquant's 'thick sociological' understanding of the function of welfare and penal systems under neoliberalism (Wacquant 2010) to explore the changing role of social work during pandemic. By exploring contemporary discourses concerning the protection of children, we draw on Bourdieu's (1999) notion of the bureaucratic field to propose that pandemic has the potential to escalate the weaponising of welfare as accepted functions of the field of contemporary child and family social work. We situate this within the scholarship of Wacquant (2010) and Foucault (1975), which outlines the function of power exercised through the penal functions of the state and its welfare function, in the context of neoliberalism. Key to this understanding of neoliberalism the 'left hand' and the 'right hand' of the state, characterised by its respective social and enforcement functions, exists to administer a social and economic programme that promotes deregulation of capital whilst maintaining regulation and control of working class populations.

Drawing on this theoretical body of work, social work is positioned in the juggling act between the social and the penal functions of the state. Crossley (2016), drawing on Wacquant (2010, identifies the ways in which official discourses of the state articulate concepts of child and family welfare as necessarily punitive and assertive. The state's symbolic power thus diagnoses and prescribes the solution to a range of social problems. As holders of legitimated symbolic capital social workers are caught in a struggle between managing and negotiating the dilemmas of welfare and enforcement (Garrett, 2007a). It is within this theoretical framing that we will explore the changing fields of social work during pandemic and the implications for practice. 


\section{The field of UK-based child protection social work}

The association between the actors/agencies within the field of child protection is relational, each connected primarily through difference (Bourdieu 1998). As a site of power, and a mass of cultural and economic capital, the local authority is dominant. At the opposite end of the social space, the family remain a microcosm. Movement within the social space of child protection is wholly dependent on the type and structure of capital held by each actor or agency within the field (Bourdieu 1989), yet the rules of progression are mostly unwritten and could be likened to that of a game, or illusio. Within this highly-staked illusio of child protection there is an underlying acknowledgment that, if the risk of harm is not reduced, the child will be removed from their parents' care. For a parent, these are very high stakes indeed.

The illusio of child protection in the UK and its associated "dangling of power" has been consistently confusing for children and families, particularly when it can influence and elevate the actor's positioning in the field (Aguilar and Sen 2009:432). COVID-19 has further changed the illusio of child protection, with confusing and contradictory commands being issued by the UK Conservative government, to be followed by all households including those with social workers. The replacement of protective welfare with disciplinary welfare was reported daily, for example $£ 100$ on-the-spot police penalties for 'breaking the rules' of a new, highly-staked illusio from which people can die (Metropolitan Police 2020). Community members, along with families in the child protection system, were being increasingly monitored by their neighbours, their communities, their family and friends and now by the State, the sudden explosion in the use of technology leaving families unaware as to who is watching them, and when - an ultimate and solemn nod to Foucault's Panoptican.

The illusio of child protection however took a more sinister turn during the lockdown period of COVID-19, with the government tossing the rulebook (in the form of protective legislation) out of the window and abolishing protective welfare for children in care (The Adoption and Children (Coronavirus) (Amendment) Regulations 2020). This was despite the solidarity and cohesiveness within the social work community, and without indication that social workers were unable to discharge their duty. Featherstone et al's (2018) social model response to child protection has tried to shift the professional gaze away from individuals (still the microcosm within the field of child protection social work, yet bearing the responsibility for every issue faced by them and their child) to communities. Indeed, whilst Wacquant (2016:4) reminds us 
of the cultural trope of individual responsibility, child protection social work still sits uncomfortably as an enforcer "whose selective and aggressive deployment in the lower regions of social space is constitutively injurious to the ideals of democratic citizenship". In turn, the pandemic social work response has been to once again focus on the family's habitus. This then begs the question as to why families are viewed as risky (and child protection laws remain the same), whilst children's homes and foster carers are deemed worthy and safe enough to abolish protections?

\section{Digital Social Work and Pandemic}

The COVID-19 pandemic has necessitated an escalation of digital technology as the dominant vehicle to enable engagement and interaction with children and their families. Social workers quickly harnessed the use of mobile technologies to undertake virtual practice with children and their families, including the use of screen based technology. Within days a lexicon of virtual statutory visits and meetings and remote working was incorporated into practice; as the electronic and digital 'turn' within social work, ruptured into a digital shock.

In Discipline and Punish, Foucault (1975) describes 'lock up' measures to contain the plague, recounting how such a crisis enables and provides rationale for the full articulation of a disciplining and surveying society. The plague requires segregation, categorisation, sight of and permanent self-reporting of the populace, enabling complex and auto-functioning mechanisms of surveillance and control to pervade society for inhabitants' own good. Foucault's (1975) description of “...each individual fixed in his place” (p196), required “...to appear at the window.... answering to his name and showing himself when asked" (ibid; p176) resonates with how children's social work practice in the UK has been forced to adapt to the COVID-19 pandemic

With the overnight closing of schools and the immersion of children into domestic settings, normal avenues of safeguarding support and recognition of abuse was severed. Within the UK, this disruption to the professional gaze has coincided with a palpable description of children's social work as a distinctly visual practice of surveillance and risk identification, with a chorus of appeals from government ministers and children's charities for workers to 'see' (Talbot, 2020), 'knock on doors' (Richardson, 2020) and have 'visibility' (Weale, 2020) of children. 
As the ability of multi-professionals to see is interrupted, the purposeful need to 'have eyes' on children is re-articulated (Weale and Adams, 2020), seemingly as the primary skillset of social work practitioners. In this way, the social worker is recast as Foucault's syndic, charged with observing the child's face at the window, on the doorstep or through a two dimensional screen as a primary mechanism of safeguarding. This narrative of a disciplining and assertive professional gaze, synonymous with notions of muscular social work practice (Featherstone et al, 2014) appears reinvigorated by well-placed and appropriate concerns about the absence of proximity and interruption of dialogue with children. Digitally enabled 'windows' into children's home environments have provided a solution for some of these concerns, even if this is accepted as inferior to the embodied presence of practitioners in children's lived environments (Ferguson, 2011, SWE guidance 2020).

Invoking Wacquant's description of the modern bureaucratic field (Wacqaunt, 2016), the (re)assertion by government of children's social work practice as one of risk identification and familial inspection (or policing) reinforces a punitive and remasculinized vision of child welfare. In this context, the purposeful use of mediated technology in social work, has been quickly embraced as a legitimate and enabling vehicle to continue these disciplining and surveying practices.

Yet, the framing of statutory visits functioning as a purely visual audit of children's safety is misguided. Cossar et al (2013) reminds us that safety for children comes with meaningful, prolonged and persistent encounters and trusting relationships. In this sense, digitized and mediated practice offer potential to be harnessed to promote relationships and the inclusion of children, young people and their families (Jeyasingham, 2020). Indeed, contemporaneous reflections from practitioners throughout the pandemic suggest regular online conversations through text-based media have assisted with improved engagement and acceptance of support and help, and the use of 'virtual windows' are most effective when completed in collaboration and negotiation with service users (Bowyer and Featherstone, 2020).

\section{Extra-familial harm and pandemic}

With the acknowledgement of 'extra-familial' harm in Working Together to Safeguard Children (HM Government, 2018), a new social work field emerges. Extra-familial contexts present new challenges for social workers (Firmin, 2020) who are tasked with responding to a range of harms in spaces outside of the family home. Bourdieu's theory of social reproduction 
(Bourdieu, 1986) has provided a frame for understanding young people's experiences of harm beyond their homes (Firmin, 2017), signalling the mutually constitutive relationship between young people's behaviour, the social contexts in which they operate, and the acquisition (or not) of capital as a mediator of harm. Therefore, it has been proposed that that child protection interventions in extra-familial contexts might focus on increasing a young person's capital - to bolster the resources they have available to navigate harmful contexts, or address the harmful 'rules at play' through a range of interventions, including changes to physical design and introducing community guardians (Firmin, 2017).

The extension of the child protection lens into extra-familial contexts flexes the powerful 'left arm' of the state in a broader range of public spaces (Wacquant, 2010; Wroe and Lloyd, 2020). If safety is created by increasing a young person's capital and disrupting the harmful 'rules' of a given social field (Firmin, 2017), those seeking to protect children should be in the business of elevating the status of young people, allowing them to re-write the rules, and to amass capital (Lavie-Ajayi and Krumer-Nevo, 2013). However, some have warned that interventions into extra-familial harms, such as those related to drug trafficking, whilst ostensibly seeking to create safety for young people and communities, are experienced as acts of symbolic power "provoking increased (and negative) attention to affected neighbourhoods, through racialised and sensationalist reporting" (Mason, 2019:11) resulting in social exclusion, damaged opportunities and anxiety (see Wroe and Lloyd, 2020).

Symbolic power is exercised in a number of ways. Child protection agencies, as sites of amassed capital, dictate what is knowable and sayable about the types of harms young people encounter beyond their front doors. They write the rule book of legitimised harms in extrafamilial contexts. Poverty, poor housing, inadequate asylum and immigration processes and racism within education establishments (for example) cause a range of significant harms to young people that are likely to be escalated by pandemic and the looming recession. Yet these are not the extra-familial harms reflected in social work assessments. Simultaneously, the child protection lens teaches professionals and lay people, to read a range of childhood behaviours (such as cannabis use and sexual activity) through the lens of abuse and exploitation. Social ills, such as poverty and racism become unknowable and unsayable in the social work field, distilled into individual risks associated with 'county lines' or 'child criminal exploitation'. 
This can escalate notions of risk and bring young people under the lens of statutory assessment, monitoring and surveillance whilst leaving unexplored opportunities to create structural safety.

COVID-19 has led to a range of panicked reactions, accusations and inferences about the extent to which lockdown will create new opportunities for harm in extra-familial contexts (NYA, 2020). Foucault (1975) describes 'crisis' as enabling and escalating the disciplining and surveilling of society. Indeed, powerful 'risk' narratives are emerging that justify a range of intrusive interventions and surveillance of young people's private and public lives. Taking 'county lines' as an example, the pandemic has been framed as an 'opportunity' for harsher policing of county lines 'drug dealers' (Bulman 2020a). Inevitably, young Black males become subject to the disciplining lens of 'crisis'. Young Black males are over-represented in 'county lines' cohorts (CSPRP, 2020) where the state dictates they are victims, and in 'gangs' cohorts (Amnesty, 2018), where the state dictates they are criminals. Simultaneously, Black people are disproportionately targeted under Coronavirus laws (ITV, 2020) whilst also at a higher risk of unemployment and mental health crisis as a result of the pandemic (Sheffield University, no date; Guardian, 2020). Safeguarding, crime prevention and public health safety converge under 'crisis' to double-down on the surveilling and monitoring of racialised groups of young people. A National Youth Agency (NYA, 2020: 7) report on gangs and exploitation during Covid-19 claims "the pandemic has amplified vulnerabilities and exposed more young people to gangassociated activities and exploitation", despite evidence (in the same report) that missing episodes, drug arrests, 'county lines' activity, serious youth violence and 'gang' activity have decreased during lockdown. Discourses of risk legitimise the penal and welfare functions of the state (Wacquant, 2010), in this case through the (necessary) accumulation of funding for youth services, but at what cost? Alternatively, through processes of critical professional reflection and engagement with young people, could social workers flex their amassed capital to leverage resources for young people without resorting to deficit narratives of risk? Repositioning themselves as agents of state capital to social capital agents (Lavie-Ajayi and Krumer-Nevo, 2013) for young people?

\section{Conclusion}

The COVID-19 pandemic compounds the instability of a child welfare system already in crisis (Care Crisis Review, 2018). We are experiencing the de-regulation of hard won protections for 
children alongside an increase in proceedings and referrals to foster care, heightened poverty and a reduction in support (Bulman 2020b). All will disproportionately impact classed and racialised families.

The UK Government is committed to a disciplinarian approach that distils economic, social and health crises into a matrix of individual responsibilities and choices, from punitive fines through to the blaming narrative of 'covidiots'. Social work reproduces this punitive lens through discourses of risk and complicated professionalised and bureaucratic assumptions and practices that often bear little resemblance to the lives and needs of families. Dictating what is knowable, sayable and seeable as harm, risk, and opportunities for safety, the illusio of child protection is incomprehensible and incoherent. Simultaneously, families are made responsible for an array of risks they pose to themselves and others, and are stripped of material and social resources. Families are invited into an illusio in which staying at home is both safe and dangerous, going to school is both responsible and risky, and going to work is both essential and deadly.

With the outcome of pandemic still unknown, the game is not over. Social work is thereby afforded an opportunity to interrogate what is knowable and sayable about the lives of families, and to admit that we too do not understand the rules of this game, despite being professionally equipped to play it. We need to challenge the rule of risk that blinds us to the future possibilities and demands for safety that are right in front of us.

\section{References}

Aguilar, J.P. and Sen, S. (2009) Comparing Conceptualizations of Social Capital. Journal of Community Practice, 17 (4), 424-443.

Amnesty (2018). Trapped in the Matrix: Secrecy, stigma, and bias in the Met's Gangs Database. (pdf) Available at: Secrecy, stigma, and bias in the Met's Gangs Database. [Accessed 25 June 2020]

Bourdieu, P. (1999) 'The weight of the world: social suffering in contemporary society', Polity Press, Cambridge.

Bourdieu, P. (1989) 'Social Space and Symbolic Power', Blackwell Publishers

Bourdieu, P. (1986). The forms of capital. In J. G. Richardson (Ed.), Handbook of theory and research for the sociology of education (pp. 46-58). New York: Greenwood Press. 
Bulman, M (2020) Coronavirus: County lines drug dealers 'stick out like a sore thumb' during lockdown, say police [online] https://www.independent.co.uk/news/uk/crime/coronaviruslockdown-county-lines-drugs-street-police-arrest-a9473301.html [accessed 24/06/20]

Bulman, M (2020) Surge during pandemic of children needing foster care as more families reach 'crisis point'[online] https://www.independent.co.uk/news/uk/home-news/coronavirusuk-foster-care-children-barnardos-a9579651.html [accessed 01/07/20]

Care Crisis Review (2018). Care Crisis Review: Options for Change. (pdf) Available at: https://www.frg.org.uk/images/Care_Crisis/CCR-FINAL.pdf. [Accessed 25 June 2020]

Child Safeguarding Practice Review Panel (CSPRP) (2020). It was hard to escape: safeguarding children at risk from criminal exploitation. (pdf) Available at https://assets.publishing.service.gov.uk/government/uploads/system/uploads/attachment_data /file/870035/Safeguarding_children_at risk from_criminal exploitation_review.pdf.

[Accessed 25 June 2020]

Cossar, J, Brandon, M., Bailey, S., Belderson, P., Biggart, L (2013) “It takes a lot to build trust' Recognition and Telling: Developing earlier routes to help for children and young people', Office of the Children's Commissioner for England, [online][accessed 28th June 2020] https://www.uea.ac.uk/documents/3437903/0/OCC+Recognition+and+Telling+report.p df/923aec11-0221-4d54-8c77-f83189e9e02d

Crossley, S. 2016, "'Realising the (troubled) family', 'crafting the neoliberal state'", Families, Relationships and Societies, vol. 5, no. 2, pp. 263-279.

Featherstone, B. \& Bowyer, S. (2020) 'Social Work With Children and Families in the Pandemic (part three)' Research in Practice' Blog [online] [accessed online 24th June 2020]

Featherstone, B., White, S. \& Morris, K. 2014, 'Re-imagining child protection: towards humane social work with families', Policy Press, Bristol.

Featherstone, B., Gupta, A., Morris, K. and White, S. (2018) 'Protecting children : a social model. Bristol': Policy Press.

Ferguson, H. 2011, 'Child protection practice', Palgrave Macmillan, Basingstoke.

Firmin, C. (2017). Contextual Safeguarding: An overview of the operational, conceptual and strategic framework. [pdf] Available at: https://www.contextualsafeguarding.org.uk/assets/documents/Contextual-SafeguardingBriefing.pdf. [Accessed 25 June 2020]

Firmin, C. \& Lloyd, J. (2020). Contextual Safeguarding: A 2020 update on the operational, strategic and conceptual framework. (pdf) Available at https://contextualsafeguarding.org.uk/wp-content/uploads/2020/05/CS-Briefing-2020FINAL.pdf. [Accessed 25 $5^{\text {th }}$ June 2020]

Foucault, M. (1975) 'Discipline and Punish - The Birth of the Prison', Vintage Books, New York: 1995 
Garrett, P.M. (2007a) Making social work more Bourdieusian: why the social professions should critically engage with the work of Pierre Bourdieu. European Journal of Social Work, 10 (2), 225-243.

Guardian (2020). Covid-19 affects BAME youth mental health more than white peers - study. (online) Available at https://www.theguardian.com/society/2020/jun/21/covid-19-hits-bameyouth-mental-health-worse-than-white-peers-study. [Accessed 25 June 2020]

HM Government. (2018). Working Together to Safeguard Children. A guide to inter-agency working to safeguard and promote the welfare of children. (pdf). Available at: https://assets.publishing.service.gov.uk/government/uploads/system/uploads/attachment_data /file/77 9401/Working_Together_to_Safeguard-Children.pdf. [Accessed 25 June 2020]

HM Government (2020) The Adoption and Children (Coronavirus) (Amendment) Regulations 2020 Crown Copyright

ITV (2020). BAME people 50\% more likely to receive coronavirus lockdown fines, MPs told. (online) Available at: https://www.itv.com/news/2020-06-17/bame-people-50-more-likely-toreceive-coronavirus-lockdown-fines-mps-told/. [Accessed 25 June 2020]

Jeyasingham, D. (2020) "Entanglements with offices, information systems, laptops and phones: How agile working is influencing social workers' interactions with each other and with families", Qualitative Social Work, vol. 19, no. 3, pp. 337-358.

Lavie-Ajayi, M. \& Krumer-Nevo, M. (2013). In a different mindset: Critical youth work with marginalized youth. Children and Youth Services Review, 35, 1698-1704

Mason. W. (2020). 'No One Learned': Interpreting a Drugs Crackdown Operation and its Consequences Through The 'Lens' of Social Harm. The British Journal of Criminology, 60:2, $382-402$.

Metropolitan Police (2020) Coronavirus (COVID-19) Police Powers [online] https://www.met.police.uk/advice/advice-and-information/c19/coronavirus-covid19/coronavirus-covid-19-police-powers/ [accessed 24/06/20]

National Youth Agency (NYA) (2020). Hidden in Plain Sight. Gangs and exploitation: A youth work response to COVID-19. (pdf). Available at: https://nya.org.uk/wpcontent/uploads/2020/06/NYA-Hidden-in-Plain-Sight-1.pdf. [Accessed 25 June 2020]

Sheffield University (no date). Coronavirus recession threatens to worsen racial inequalities in youth unemployment, researchers warn. (online). Available at: https://www.sheffield.ac.uk/news/nr/coronavirus-recession-threatens-worsen-racialinequalities-youth-unemployment-black-lives-matter-1.890568. [Accessed 25 June 2020]

Social Work England (2020), 'Social Work England and PCFSW Best Practice Guide for Assessing Online Risks, Harm and Resilience and Safeguarding of Children and Young People Online [online PDF] [accessed online 27th May 2020] https://esafeguarding.org/publications/PSW=and-SWE-Best-Practice-Guidance-forAssessing-Online-Risks,-Harm-and-Resilience-and-Safeguarding-Children-and-YoungPeople-Online-2020-05-26.pdf 
Richards, H. (2020) 'Tiny fraction of 'at risk' children attending schools' BBC news [online] [accessed online 22nd April] https://www.bbc.co.uk/news/in-pictures-52370968

Talbot, A. (2020) 'What is socially distanced child protection and can it work?' Children's Commissioner [online][accessed $\quad$ 16th $\quad$ April 2020] https://www.childrenscommissioner.gov.uk/2020/04/16/what-is-socially-distanced-childprotection-and-can-it-work/

Wacqant, L. 'Bourdieu, Foucault and the Penal State', in - Zamora, D. \& Behrent, M.C. 2016, Foucault and neoliberalism, Polity, Cambridge.

Wacquant, L. (2010) "Crafting the Neoliberal State: Workfare, Prisonfare, and Social Insecurity", Sociological Forum, vol. 25, no. 2, pp. 197-220.

Weale, S. \& Adam,s R. (2020) 'Make It Compulsory For Vulnerable Children To Go To School' Guardian Newspaper, [online] [accessed online 22nd April] https://www.theguardian.com/education/2020/apr/22/make-it-compulsory-for-vulnerablechildren-to-go-to-school-no-10-urged

Weale, S. (2020) 'Fears for Child Welfare As Protection Referrals Plummet' Guardian newspaper [online] [accessed online 8th April] https://www.theguardian.com/society/2020/apr/08/fears-for-child-welfare-as-protectionreferrals-plummet-in-england

Wroe, L. E. \& Lloyd, J. (2020). Watching Over or Working With: Understanding social work innovation in response to extra-familial harm. Social Sciences, 9:4, 213-218

This work has not been supported by any funding body or grant.

The Authors declare that there is no conflict of interest. 